\title{
Development of IT-Technologies in Labor Standardization and Quality Assessment of Standards: Challenges and Ways of Solution in Russia
}

\author{
${ }^{1}$ Vadim A. Schekoldin, ${ }^{* 2}$ Irina V. Bogatyreva, ${ }^{3}$ Larisa A. Ilyukhina, ${ }^{4}$ Vyacheslav M. Kornev \\ ${ }^{1}$ Candidate of Economic Sciences, Professor of Department of Economics of Labor and Personnel Management, \\ Samara State University of Economics, Samara, Russia. \\ ${ }^{2,3}$ Candidate of Economic Sciences, Associate Professor of Department of Economics of Labor and Personnel \\ Management, Samara State University of Economics, Samara, Russia. \\ ${ }^{4}$ Doctor of Economics, Professor, Vice-Rector for Correspondence and Additional Education, Samara State \\ University of Economics, Samara, Russia. \\ E-mail: "scorpiony70@mail.ru,vadimak@yandex.ru, laresa@inbox.ru,kornev@sseu.ru
}

\section{Received: $27^{\text {th }}$ June 2018, Accepted: $20^{\text {th }}$ July 2018, Published: $3^{\text {st }}$ August 2018}

\begin{abstract}
The main tendencies of using IT-technologies in work standardization are considered in the article. Development of Information Technologies in work standardization gives a possibility to reduce labor input of specialists in work standardization and to increase efficiency of their working hours. Special attention is paid to the analysis of the quality of labor expenditures standards: the reasons for poor quality of work standards at Russian enterprises are considered, the level of intensity of norms, distribution of workers according to the level of performance of standards, the specific weight of technically (scientifically) based standards are analyzed. The authors of the article presented the approximate scope of work of the specialist in work standardization and the structure of his automated workplace. The order and methods of development of automated systems of work standardization are shown, the algorithm of calculation of annual economic benefits from introduction of the automated standardization system is developed, and the example of calculation of labor input of the performed works in a shop of one of the Samara enterprises is given. The flow chart of the analysis of intensity of the existing standards is submitted, the main tendencies of improvement of a condition of work standardization at enterprises are given.
\end{abstract}

Keywords: Automated Workplace, IT- Technologies, Quality of Standards, Intensity of Standards, Work Standardization, Work Standards, Automation Efficiency.

\section{Introduction \\ Establishing a context}

Increase in the role of work standardization as the most important function of production management is one of factors of management of labor productivity in modern Russia. Interest of enterprises in reduction of production expenditures (works), including labor costs, applies high requirements to organization of work on labor standardization, level of their informatization, quality of the established standards of labor expenditures, their progressiveness, reasonability equal to intensity. The Russian employers quite often underestimate the role of work standardization in increase in production efficiency. Weak informatization of work on labor standardization, use of unreasonable work standards and the outdated regulatory framework, reduction of the share of workers, consumed with labor standardization, adaptation of work time standards to the necessary salary level while application of low tariff rates does not stimulate high labor productivity level, they impede full disclosure and use of creative potential of workers.

Work standardization is quite labor-intensive process because of considerable volumes of the processing information. In the period of common usage of computer IT- technologies for enterprises, there appeared an opportunity to automate the main activities on work standardization: the systems of calculation of time standards with use of computer technologies are created as autonomous systems; the systems of calculation of time standards in a uniform cycle with the automated design of technological processes are developed and introduced.

However, the scope of work by the automated standardization of technological processes is insufficient. By means of IT- technologies at production only $5-7 \%$ of work is carried out. The reason is in lack of coordination of works on creation and application of software, it leads to unjustified scatterating of forces and duplication of works. It also indirectly affects the quality of work standards. High labor input of specialists in work standardization and inefficient use of their working hours does not allow analyzing the existing norms in more details and developing activities aimed at increase in their quality. Deterioration in quality of existing standards at enterprises is also connected with the fact that for many years Russia did not reconsider uniform and standard interindustrial and industrial norms and 
standards. Technical, organizational, psychophysiological and economic factors, which influence labor expenditures, are not considered at some enterprises while setting standards. Consequently, the work standards, operating at Russian enterprises can not be considered technically (or scientifically) grounded.

\section{Reviewing the Literature}

While rapid development of information technologies, there is a gradual transformation of content of the labor process (Simonova et al., 2016) [1], the importance of work standardization increases as the most important function of production management. Scientific works of many Russian and foreign scientists are devoted to research of issues of informatization of work standardization and quality improvement of standards at enterprises.

The prospects of use of microelement work standardization with application of information technologies and their influence on improvement of quality of the defined standards are considered in works of Sukhanova \& Pikalin (2017) [2], Shchekoldin (2013) [3], Miuskova \& Kireeva (2013) [4], Zainullina (2012) [5], Maximov (2014) [6], Malinin, Bakhtizina \& Startseva (2016) [7].Development of Information Technologies is a necessary element of improvement of the available and created software for designing labor standards (Byichin \& Novikova, 2018) [8]. Scientifically based microelement standards of time for certain motions and their complexes of the universal nature allow covering all work types of a person and providing equal intensity of work standards (Miuskova, 2004) [9]. These systems of microelement work standardization are the most important research problems of motion and time (Barnes, 1980; Meyers \& Stewart, 2002) [10-11]. Some tools of methods of time measurement (MTM) are used for modeling and forecasting of separate elements of production (Khalid, 2011) [12]. In the XX century many similar systems of microelemets were developed. For example MTM (Methods-Time Measurement) was created in the late forties by the group of scientists from the USA (Maynard, Stegemerten \& Schwab, 1948) [13]. Gradually there appeared other similar systems, such as MTM-1 (Karger \& Bayha, 1987) [14], MTM-2, MTM-3, MCD, MTM-V, MOST, MODAPTS. The MOST method is nowadays widely used in foreign practice. It is considered as the most effective and inexpensive (Puvanasvaran, Mei \& Alagendran, 2013) [15]. In Russia the basic microelement system (BMS) was created in the eighties, and after that there was BMS-1. Such typical ASM is meant to be used by organizations, which are engaged in development of standard materials on labor, and also by enterprises while developing factory time standards and calculating standards (Loktev, 2006) [16]. Development of IT-technologies reduces labor input of specialists in work standardization and increases efficiency of use of their working hours (Shchekoldin, Bogatyreva \& Ilyukhina, 2018) [17]. It goes without saying that modern computer technologies, applied for development of work standards allow increasing quality and reducing labor input of their development. They accelerate calculation processes of standards of time and output quota on new products, preparation of reporting on a condition of work standardization and the quality of existing standards. In this regard there is a need of consideration of work standardization at an enterprise as the process integrated into activity of a company (Shutina, 2009) [18]. Nowadays many economists agree that there is a close interrelation between standartization and labor productivity (Shchekoldin, 2011; Bogatyreva, 2016) [19-20]. It is noted in many scientific works that labor standardization presupposes the fullest use of available reserves of labor productivity and effective performance of work (Shchekoldin, Bogatyreva \& Ilyukhina, 2017) [21]. The quality of existing standards, decrease in losses of working hours directly influences labor productivity of employees (Collewet \& Sauermann, 2017; Durana, Cetindereb \& Emre Aksuc, 2015; Espinosa-Garza, Loera-Hernández \& Antonyan, 2017) [22-24]. Work standards should be scientifically based, providing sufficient intensity of labor power in the work process for the purpose of achievement of its high efficiency (Vaisburd et al., 2016) [25]. They define a measure of consumption (quotation, earnings), support economically feasible ratios between increase in work productivity and salary. Undoubtedly, there is an interrelation between the wage rates and labor productivity, and it becomes an object of a number of scientific studies (Riley, Rosazza Bondibene, 2017) [26].

\section{Establishing a Research Gap}

Russian enterprises accumulated certain experience of automation of work standardization. However, the automated information processing systems, which are available at enterprises, deal mostly with work on calculation of salary. The whole complex of problems of work standardization at the most Russian enterprises is not covered by automation: account and report on work standardization, analysis of the condition of work standardization, development of scheduled plans of replacement and reconsideration of standards, decrease in labor input of production and control after their performance. Specialists in labor do not have enough time for the detailed analysis of the standards, operating at Russian enterprises, and for development of activities, aimed at increase in their quality. Therefore, the results of the research, conducted in 2008, showed that only $4 \%$ of the 
surveyed enterprises dealt with issues of reconsideration of the existing work standards (Kichigin, 2014) [27]. Absence of the uniform and typical interindustrial and industrial norms and standards corresponding to the modern conditions of the Russian production makes enterprises to use outdated standard materials.

Decline in quality of standards is connected with the general deterioration in the condition of work standardization and is a consequence of problems in the field of compensation of employees of the Russian enterprises. "A tariff rate is the fixed amount of compensation of an employee for performance of work standards of a certain complexity (qualification) for a time unit" (The Labor Code of the Russian Federation, Article 129). At low tariff rates and groundless standards, a favorable environment for production voluntarism is created when the salary of workers depends not on the work results, but on the will of the linear head.

The relevance of the research on issues of application of IT-technologies in work standardization and increase in quality of standards is defined by the following factors:

- increase in the role of labor standardization as one of the most important functions of production management;

- high labor input of calculations, which is caused by complication of production;

- an insufficient scope of work on labor standardization at enterprises by automated systems

\section{Stating the Purpose}

The goals of the research, which results are reflected in this article, are studying of the main tendencies of use of IT-technologies in work standardization and analysis of problems, connected with the quality of work standards, operating at Russian enterprises, and search of ways of their solution. In order to achieve the stated goal, the following objectives were solved in the course of the research:

- the approximate scope of work of the specialist in labor standardization and the structure of his automated workplace is given,

- the order and methods of development of automated systems of work standardization are justified,

- the algorithm of calculation of annual economic benefits from introduction of the automated standardization system is developed,

- $\quad$ the example of calculation of labor input of the performed works in a shop of one of the Samara enterprises is given;

- $\quad$ the flow chart of the analysis of intensity of the existing standards is presented,

- quality indicators of work standards are analyzed: level of accomplishment of standards (intensity of norms), distribution of workers according to the level of performance of standards, the specific weight of technically (scientifically) based standards, the main tendencies on improvement of the state of work standardization at enterprises are developed.

\section{Materials and Methods}

Practice and scientific research shows that ITtechnologies in labor standardization can be successfully applied for: setting time standards and manufacture of products; development of standard materials for work standardization; calculation of optimum norms of service and quantity with use of economic and mathematical methods; processing of results of survey on expenditures of working hours (photos of the working day, stop-watch reading); preparation of reporting on a condition of work standardization and the quality of the existing standards (Figure 1).

\section{IT-technologies in work standardization}

\section{Main tendencies of application}

\begin{tabular}{|c|c|}
\hline $\begin{array}{c}\text { Automation of calculation of standards for } \\
\text { output } \\
\text { quantity with use of economic and mathematical } \\
\text { methods }\end{array}$ \\
Analysis of a condition of work standardization \\
processes
\end{tabular}




\section{Figure 1. Main Tendencies of Application of IT-Technologies in Work Standardization.} Source: It is drawn by the Authors.

1. Automation of calculation of standards for output. Automation of calculation of work standards includes creation of the system of calculation of time standards with application of IT- technologies, generally operational ones, functioning in conditions of the individual labor organization. Autonomous systems (program-methodical complexes of automation of standardization of mechanical processing by cutting) and the systems of automated designing of technological processes and their standardization are among such technologies. The latter are the most perspective and effective tendencies, because initial information is also used for calculation of time standards, and it correspondingly reduces labor input of its preparation. These systems do not demand special preparation of large volume of initial data, obtained in the course of designing of technological processes. They represent higher level of standardization.

2. Development of standard materials for work standardization.

The condition of technical standardization at enterprises depends on the regulatory framework and on the fact, whether there are standards for all types of work and their quality. In order to develop time standards it is necessary to define dependence of time of performance of operation elements on factors influencing their duration. Development of quantity standards presupposes finding dependence of number of employees on the factors influencing labor input of work on service and production management. The quality of standards depends on the fact how the volume of necessary initial data is reasonably determined and the factors are chosen. It is also important how accurately their influence on duration of operation or labor input of service and management is established.

3. Calculation of optimum norms of service and quantity with use of economic and mathematical methods.

The task of establishment of optimum standards of service and quantity consists in finding the most effective ratio between the amount of equipment (or work places) and the number of workers serving them. This task is multiple, difficult and labor consuming. It is solved with application of mathematical methods. It also requires a special software for automation of its solution.

4. Study of expenditures of working hours and labor processes.

Study of working hours and labor processes is one of the main research methods, which is used by specialists in work arrangement and standardization. The research results show that experts spend up to $25 \%$ of their working hours for these works. It causes the need of automation of these works.

5. Analysis of a condition of work standardization Improvement of work standardization at Russian enterprises requires the analysis of its state, which is characterized by a number of criteria. One of them is the quality of the existing standards. The analysis of the quality of norms at enterprises is carried out on indicators, presented in the Figure 2.

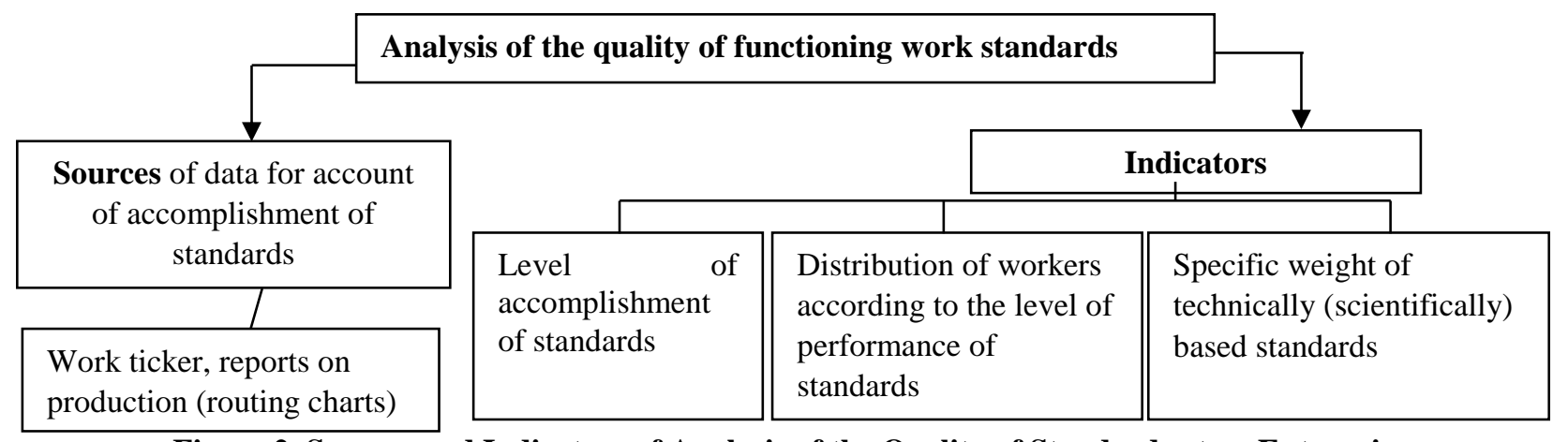

Figure 2. Sources and Indicators of Analysis of the Quality of Standards at an Enterprise. Source: It is drawn by the Authors.

The coefficient of performance of standards is used as an indicator of the level of accomplishment of standards. In dependence to the concrete manufacturing situations, various methods are used for its calculation. They are presented in the Figure 3. 


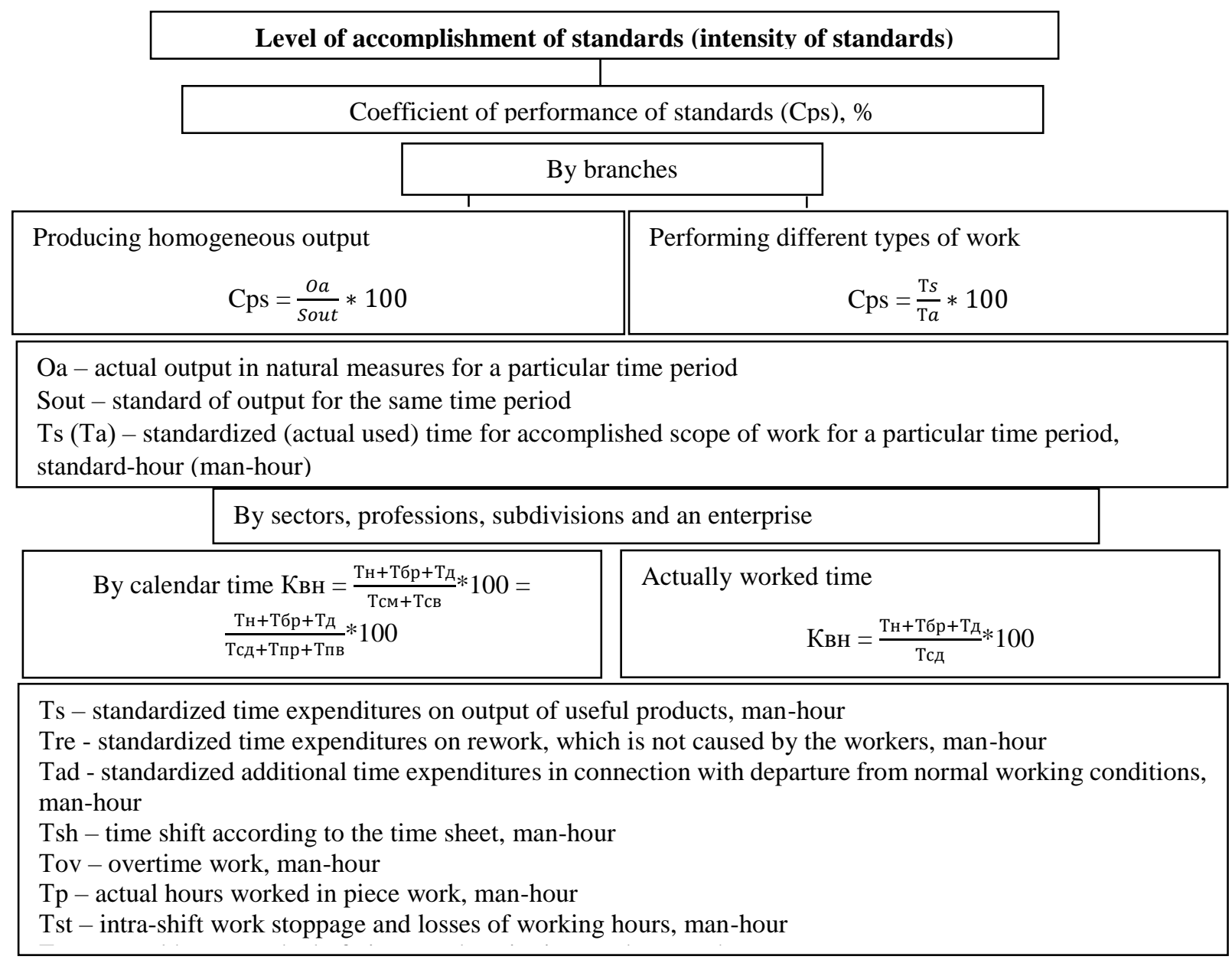

Figure 3. Determination of the Level of Intensity of Standards at an Enterprise. Source: It is drawn by the Authors.

The set of factors (inexact account of hours worked, violation of the technology, use of loose standards, qualification of workers) influences on overfulfillment of standards.
The average level of performance of standards can not authentically characterize the quality of standards since it depends on intensity of standards and individual labor productivity of workers (Figure 4

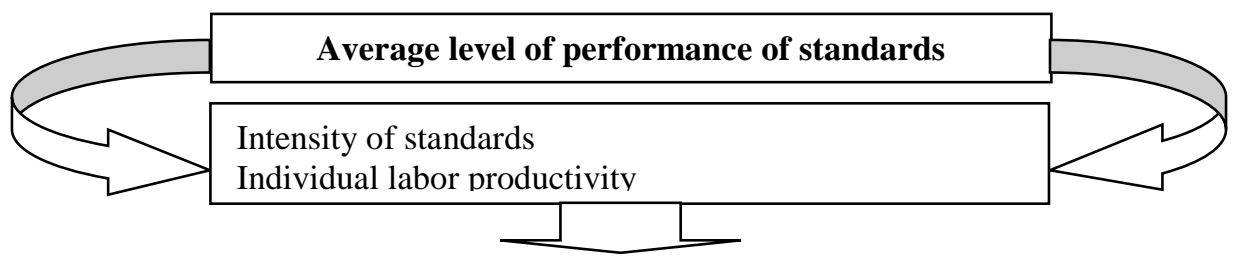

Maximum deviation of the average labor productivity of the analyzed $i$-group of workers in relation to the average labor productivitv of a bigger amount of workers (Oi).\%

$$
\begin{array}{|l|l}
\hline \mathrm{Qi}=\frac{\mathrm{M}}{\sqrt{n i}} * \sqrt{1-\frac{n i}{N}} & \mathrm{Qi}=\frac{\mathrm{M}}{\sqrt{n i}}
\end{array}
$$

$\mathrm{ni}$ - smaller amount of workers (sector, profession)

$\mathrm{N}$ - bigger amount of workers (shop, enterprise)

$\mathrm{M}$ - maximum deviation of the individual labor productivity of certain workers from the average level $(33 \%$ is accepted for machine and machine-manual work, $50 \%$ - for manual work) 
Deviation of the level of intensity of standards of the analyzed i- group of workers from the average level of intensity of standards of a bigger amount (Di)

$$
\mathrm{Di}=(\text { Cpsi }- \text { Cpsa })-\mathrm{Q} i * \frac{\text { Cpsa }}{100}
$$

Di $>0$ - the level of intensity (quality) standards in $« \mathrm{n}_{\mathrm{i}} »$ group of workers below the average level of intensity of standards of a bigger amount

$\mathrm{Di} \leq 0$ - difference in the level of performance of standards of a smaller amount of workers and bigger amount is caused by differences in labor productivity

Figure 4. Calculation of Deviation of the Level of Intensity of Standards. Source: It is drawn by the Authors.

It is possible to determine correspondence of the standards, functioning at enterprises, to socially necessary labor expenditures with the help of the indicator of intensity. These expenditures are close to the time standards in its value. They are calculated according to the centrally developed standards (interindustrial and industrial).

The account of distribution of workers according to the level of performance of standards is also performed for the analysis of the standards, functioning at enterprises (Figure 5).

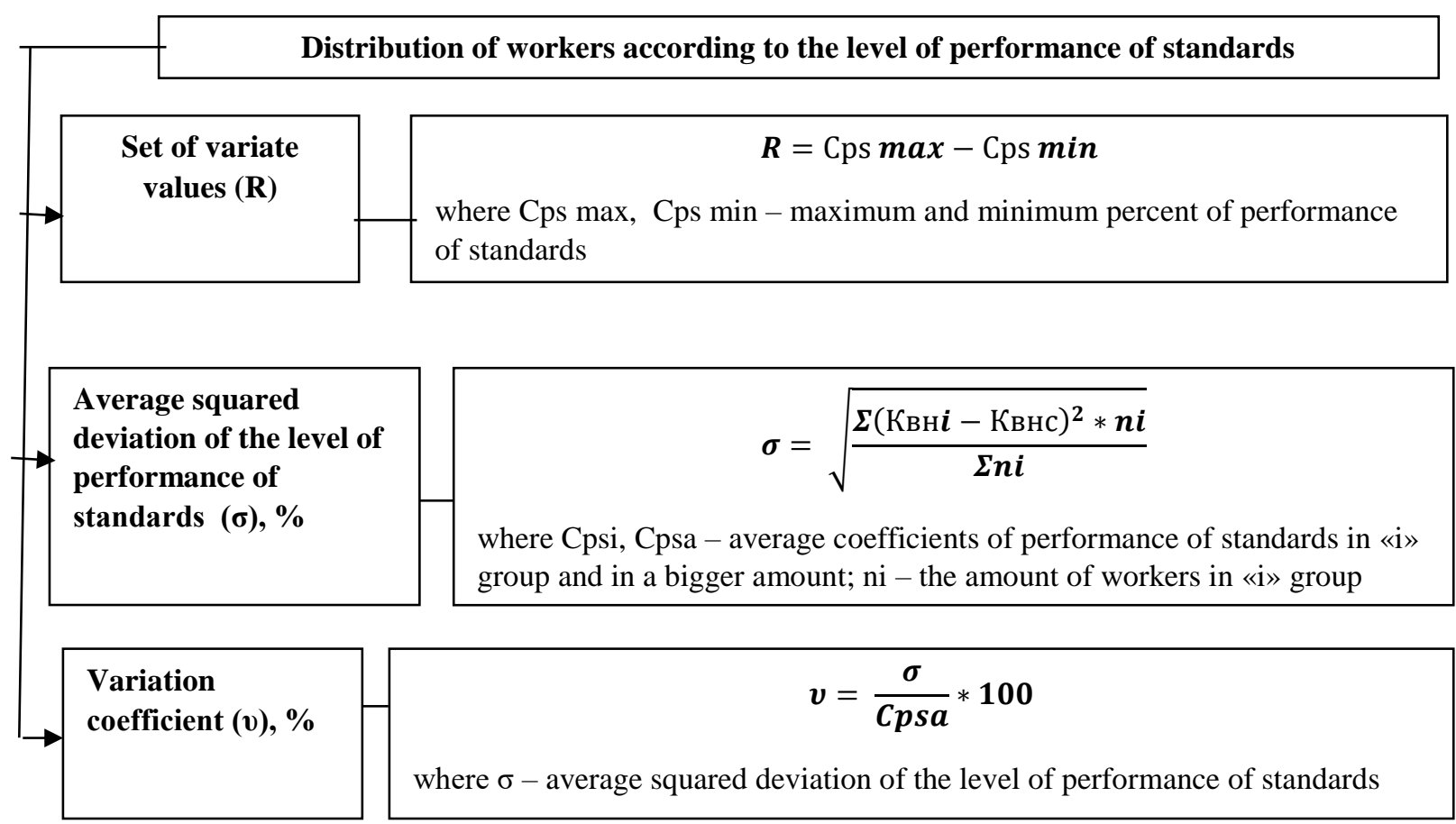

Fig. 5. Statistical Indicators of Distribution of Workers According to the Level of Performance of Standards Source: It is drawn by the Authors

The last calculation indicator of the analysis of quality of standards at enterprise is the degree of reasonability of standards (Figure 6). 


\section{Specific weight of technically (scientifically)}

based standards

\begin{tabular}{|c|c|c|c|}
\hline $\begin{array}{l}\text { By amount of } \\
\text { standards, \% }\end{array}$ & $S t b s=\frac{N t b s}{N} * 100$ & & $\begin{array}{l}\text { Ntbs - number of technically based standards } \\
\mathrm{N}-\text { total number of operating standards }\end{array}$ \\
\hline $\begin{array}{l}\text { By labor } \\
\text { input, \% }\end{array}$ & $S t b s=\frac{\mathrm{T} t b s}{\mathrm{~T} t o t} * 100$ & & $\begin{array}{l}\text { Ttbs - number of worked standard-hours on } \\
\text { performance of detail-operations, where technically } \\
\text { based standards are applied } \\
\text { Ttot - total number of worked standard-hours }\end{array}$ \\
\hline $\begin{array}{l}\text { By amount of } \\
\text { workers, \% }\end{array}$ & $S t b s=\frac{A t b s}{A t o t} * 100$ & $\rightarrow$ & $\begin{array}{l}\text { Atbs - amount of workers, which fully work on } \\
\text { technically based standards } \\
\text { Atot - total amount of workers }\end{array}$ \\
\hline
\end{tabular}

Figure 6. Determination of the Specific Weight of Technically Based Standards in Total Amount of Standards Source: It is drawn by the Authors.

Efficiency of automation of work on labor standardization

Development and introduction of the automated system of work standardization leads to economy of working hours both in the production and management spheres. The labor productivity increases, and it influences on production efficiency both at micro- and at macro levels (Lanza et al., 2013) [28]. The algorithm of calculation of the annual economic benefits from development and use of the automated standardization system is presented in the Figure 7.

\begin{tabular}{|c|c|c|c|}
\hline \multicolumn{4}{|c|}{ Annual economic benefits from introduction of the automated standardization system (Eca) } \\
\hline Production sphere & $E c a=E c p+$ & $P e * U n$ & Management sphere \\
\hline$E c p=(A b-A s) * S m *\left(1+\frac{C c}{100}\right.$ & $*(1-C i) * \mathrm{M}$ & $E c m=$ & $u) * S h *\left(1+\frac{C c}{100}\right)-O e$ \\
\hline
\end{tabular}

$E c p, E c m$ - economy in production and management spheres, rub.

$P e$ - pre-production expenses on acquisition of PC and development of a system, rub.

Un - norm coefficient of recoupment of capital investment.

$\mathrm{Ab}$ - the amount of workers in a basic period (on operating standards), man

$A s$ - the amount of workers on technically based standards, calculated in the automated regime, man

$S m$, $S h$ - the average monthly salary of employees and hourly salary of a specialist in work standardization, rub.

$C c$ - the coefficient, considering contributions to different funds.

$\mathrm{Ci}$ - the coefficient, considering increase in wage -rates (tariff pay) of employees for

work on technically based standards.

$\mathrm{M}$ - duration of validity of introduced design solutions in the considered year, month

Lim - annual labor input of work on labor standardization, performed manually, hour.

Liau - annual work labor input, performed in automated regime, hour

$\mathrm{Oe}$ - annual operational expenses (on maintenance of PC), rub.

Figure 7. The Algorithm of Calculation of the Annual Economic Benefits from Introduction of the Automated Standardization System.

Source: It is drawn by the Authors. 
In the production sphere, the economy of working hours is achieved due to decrease in labor input of production as a result of introduction of technically based standards. In the management sphere, the economy of time is formed by means of quick access to the required information and reduction of expenses of time for execution of working papers. If the economy in the production sphere does not arise or it is difficult to define, then we are limited to calculation of the economy in the management sphere.

\section{Results}

Considerable experience of application of information technologies for solution of tasks in the field of work organization and standardization is obtained by Russian enterprises. Automation of work standardization is

\begin{tabular}{|l|l|l|}
\hline \multicolumn{1}{|c|}{ Name of work } & \multicolumn{1}{|c|}{ Documents } & \multicolumn{1}{|c|}{ Frequency } \\
\hline Preparation of a draft plan on reducing labor input & Draft plan & Yearly \\
\hline $\begin{array}{l}\text { Compilation of a report on fulfillment of standards in professions, } \\
\text { sectors, and on results of photos of the working day }\end{array}$ & Report & Monthly \\
\hline Making observation and processing of photos of the working day & Photographic maps & Monthly \\
\hline $\begin{array}{l}\text { Maintenance of logs for accounting monthly salary according to the } \\
\text { piece-bonus system }\end{array}$ & Log & Monthly \\
\hline $\begin{array}{l}\text { Maintenance of logs of standards on detail-operations and change } \\
\text { of standards and rates }\end{array}$ & Log of standards and rates & $\begin{array}{l}\text { By perforce of } \\
\text { by plan }\end{array}$ \\
\hline Journaling of labor-consuming of details & Journal file of labor input & Monthly \\
\hline Completion of work orders & Work orders & Daily \\
\hline Making stop-watch reading and its processing & $\begin{array}{l}\text { Map of chronological } \\
\text { observation }\end{array}$ & By perforce \\
\hline Preparation of a report on reduction of labor input & Report & Quarterly \\
\hline Standardization of technical processes on new outputs & $\begin{array}{l}\text { Technological and } \\
\text { standardizing map }\end{array}$ & By perforce \\
\hline
\end{tabular}

\section{Table 1.Work Structure of a Specialist in Work Standardization} Source: It is drawn by the Authors.

Determination of expediency of automation as well as detection of the correspondence of the list and the complexity level of the performed work with duty regulations of a specialist in work standardization is possible only by the results of analysis.

At the level of an enterprise, the structure of an automated workplace should include works on the analysis of a condition of labor standardization, development of work standards, calculation of labor input of products and drawing up plans for its decrease, analysis of reasons and identification of guilty persons for downtime, preparation of reporting, etc. At the level of a shop, a subdivision there are absolutely another works.

On the basis of duty regulations on work standardization and analysis of work content of a specialist in labor in a subdivision (Table 1), the scope of work is made. Their performance is subject to automation:

Setting of standards on new detail-operations on the basis of time standards, and on observational and statistical data;

- Formation of the data base of standards and wage-rates and other reference data; partially implemented at a number of enterprises of the Samara region.

The object of automation in the field of labor standardization at an enterprise is work, performed by specialists in labor standardization. For determination of the list of functions and tasks, which are subject to automation, it is expedient to study the content, frequency and methods of performance of work, which is carried out by experts, the forms of in and out documentation. The example of the analysis results of the work structure of a specialist in labor standardization of a shop is presented in Table 1.
- Processing and analysis of results of photographs of the working day and stop-watch reading;

- Calculation of labor input of goods for nomenclature of the annual production program;

- Account of performance of standards on certain employees, professions, brigades, sectors, subdivisions;

- Analysis of a condition of standardization;

- Development of scheduled plans of replacement and reconsideration of standards, control after it performance; - Preparation of reporting on performance of standards, decrease in labor input, expenditure of the wages fund (Shchekoldin, 2015) [29].

Activities of a specialist in work standardization, which are included into the structure of his automated workplace (AWP), are united in 4 groups: calculation of standards of time and labor input of goods, accounting and reporting, calculations for salary and training. An operation card should be developed on each work. It determines the work structure, the list of initial information, solution methods, a form of submission of out information, frequency of performance (Table 3 ). 


\begin{tabular}{|c|c|c|c|}
\hline \multirow[t]{3}{*}{ Name of work } & Subdivision & $\begin{array}{l}\text { Labor and wages } \\
\text { department }\end{array}$ & \multirow[t]{5}{*}{ Approved by: } \\
\hline & Performer & $\begin{array}{l}\text { Engineer in work } \\
\text { standardization }\end{array}$ & \\
\hline & Technical supply & Personal computer & \\
\hline \multirow{2}{*}{$\begin{array}{l}\text { Calculation of technically } \\
\text { based standard for } \\
\text { machning }\end{array}$} & Time standard, h & 1.2 & \\
\hline & Frequency & By perforce & \\
\hline \multicolumn{3}{|l|}{ Scope of input information } & From where forthcome \\
\hline \multicolumn{3}{|c|}{ 1. Flowchart } & Production department \\
\hline \multicolumn{3}{|c|}{ 2. Time standards for machining } & $\begin{array}{l}\begin{array}{l}\text { Labor and wages } \\
\text { department }\end{array} \\
\end{array}$ \\
\hline \multicolumn{3}{|c|}{ 3. Scheduled planning standards } & $\begin{array}{l}\text { Planning and economic } \\
\text { department }\end{array}$ \\
\hline Operation & Content & Document & Indicators \\
\hline $\begin{array}{l}\text { 1. To establish the } \\
\text { structure of a } \\
\text { manufacturing operation }\end{array}$ & $\begin{array}{l}\text { 1. To find and to transfer the } \\
\text { operation structure to the } \\
\text { standardizing map }\end{array}$ & Flowchart & $\begin{array}{l}\text { Technological transfers } \\
\text { and working practices }\end{array}$ \\
\hline \multirow[t]{2}{*}{$\begin{array}{l}2 . \quad \text { To determine } \\
\text { machining time }(\mathrm{Tm})\end{array}$} & $\begin{array}{l}\text { 1. To find the parameters of the } \\
\text { labor subjects, tools, cutting } \\
\text { modes }\end{array}$ & The same & - \\
\hline & $\begin{array}{l}\text { 2. To calculate Tm for transfers } \\
\text { and for operation in general }\end{array}$ & Standardizing map & Machining time \\
\hline \multirow{2}{*}{$\begin{array}{l}3 . \text { To determine } \\
\text { auxiliary time for } \\
\text { practices (a complex of } \\
\text { practices): } \\
\text { 3.1. For setting and } \\
\text { removal of a detail }\end{array}$} & $\begin{array}{l}\text { 1. To find parameters, the } \\
\text { character and a method of } \\
\text { setting and bracing of a detail }\end{array}$ & Flowchart & $\begin{array}{l}\text { Mass of a detail, method } \\
\text { of bracing }\end{array}$ \\
\hline & $\begin{array}{l}\text { 2. To find time for these } \\
\text { parameters }\end{array}$ & $\begin{array}{l}\text { Time standards for } \\
\text { machining }\end{array}$ & $\begin{array}{l}\text { Time for setting and } \\
\text { removal of a detail }\end{array}$ \\
\hline \multirow[t]{2}{*}{$\begin{array}{l}\text { 3.2. For technological } \\
\text { transfer }\end{array}$} & $\begin{array}{l}\text { 1. To find parameters, the } \\
\text { character of a technological } \\
\text { transfer }\end{array}$ & Flowchart & $\begin{array}{l}\text { The processing type, the } \\
\text { size of a detail }\end{array}$ \\
\hline & $\begin{array}{l}\text { 2. To find time for these } \\
\text { parameters }\end{array}$ & Time standards & Time for transfer \\
\hline \multirow[t]{2}{*}{$\begin{array}{lc}3.3 . \quad \text { For } & \text { control } \\
\text { measurement } & \end{array}$} & $\begin{array}{l}\text { 1. To find parameters, the } \\
\text { character of processing, a } \\
\text { measurement method }\end{array}$ & Flowchart & $\begin{array}{l}\text { The measurement } \\
\text { method }\end{array}$ \\
\hline & $\begin{array}{l}\text { 2. To find time for these } \\
\text { parameters }\end{array}$ & Time standards & Time for measurement \\
\hline $\begin{array}{l}\text { 3.4. To determine auxiliary } \\
\text { time for an operation }\end{array}$ & $\begin{array}{l}\text { 1. To sum auxiliary time over } \\
\text { practices }\end{array}$ & Standardizing map & Auxiliary time \\
\hline $\begin{array}{l}4 . \text { To determine } \\
\text { operating time for an } \\
\text { operation }\end{array}$ & $\begin{array}{l}\text { 1. To sum } \\
\text { machining (main) and auxiliary } \\
\text { time }\end{array}$ & The same & Operating time \\
\hline \multirow[t]{4}{*}{$\begin{array}{l}\text { 5. To determine piece } \\
\text { time for an operation }\end{array}$} & $\begin{array}{l}\text { 1. To find indicators, } \\
\text { characterizing } \\
\text { maintenance of a workplace and } \\
\text { labor conditions }\end{array}$ & $\begin{array}{l}\text { Labor organization } \\
\text { map }\end{array}$ & $\begin{array}{l}\text { Indicators } \\
\text { maintenance of a } \\
\text { workplace and labor } \\
\text { conditions }\end{array}$ \\
\hline & $\begin{array}{l}\text { 2. To find time for these } \\
\text { parameters }\end{array}$ & Time standards & $\begin{array}{l}\text { Time for maintenance } \\
\text { of a workplace, leisure } \\
\text { and personal needs }\end{array}$ \\
\hline & $\begin{array}{l}\text { 3. To bring it into the } \\
\text { standardizing map }\end{array}$ & Standardizing map & \\
\hline & 4. To add it to the operating time & The same & Piece time \\
\hline \multirow[t]{2}{*}{$\begin{array}{l}6 . \quad \text { To determine } \\
\text { machine-setting time }\end{array}$} & $\begin{array}{l}\text { 1. To find indicators of } \\
\text { preparation content to work and } \\
\text { adjustment of equipment }\end{array}$ & $\begin{array}{l}\text { Labor organization } \\
\text { map }\end{array}$ & \multirow[t]{2}{*}{ Machine-setting time } \\
\hline & $\begin{array}{l}\text { 2. To find time for these } \\
\text { parameters }\end{array}$ & Time standards & \\
\hline
\end{tabular}


Helix Vol. 8(5): 3615- 3628

\begin{tabular}{|l|l|l|l|}
\hline & $\begin{array}{l}\text { 3. To bring it into the } \\
\text { standardizing map }\end{array}$ & Standardizing map & \\
\hline $\begin{array}{l}\text { 7. To determine piece- } \\
\text { costing time }\end{array}$ & $\begin{array}{l}\text { 1. To sum piece and machine- } \\
\text { setting time }\end{array}$ & $\begin{array}{l}\text { Scheduled planning } \\
\text { standards } \\
\text { Standardizing map }\end{array}$ & $\begin{array}{l}\text { Batch size. Piece- } \\
\text { costing time }\end{array}$ \\
\hline
\end{tabular}

Table 2. Operation Card of Work Performance Source: It is drawn by the Authors.

The main goal of creation of an automated workplace of a specialist in work standardization -to automate processing of information, calculations, preparation of documents to the extent possible, and it increases efficiency, reliability of information, labor productivity. The analysis, which is carried out by the scientists, has shown that automation of processing of calculations leads to reduction of time expenditures on performing calculations by 5-6 times, and on paperwork by 2-3 times.

The example of calculation of decrease in labor input of the performed works on labor standardization due to introduction of an automated workplace is presented in the Table 4. As reflected by table 4, automation of work on labor standardization is rather effective. The labor input of work was reduced almost by 11 times (2187/199).

\begin{tabular}{|l|l|l|l|l|l|}
\hline Name of work & \multirow{2}{|l|}{$\begin{array}{l}\text { Quantity per } \\
\text { year, ea. }\end{array}$} & & \multicolumn{2}{|l|}{ Labor input, hour } \\
\cline { 3 - 6 } & & Units of work & \multicolumn{2}{l|}{ Annual } \\
\cline { 3 - 6 } & & Manually & $\begin{array}{l}\text { In automatic } \\
\text { mode }\end{array}$ & Manually & $\begin{array}{l}\text { In } \\
\text { mode }\end{array}$ \\
\hline $\begin{array}{l}\text { Calculation of new } \\
\text { standards }\end{array}$ & 2060 & 0,5 & 0,05 & 1030 & 103 \\
\hline Alteration of standards & 1835 & 0,16 & 0,02 & 293 & 37 \\
\hline $\begin{array}{l}\text { Compilation of a report } \\
\text { on fulfillment of } \\
\text { standards }\end{array}$ & 4,0 & 0,2 & 48 & 2,4 \\
\hline $\begin{array}{l}\text { Compilation of a report } \\
\text { on reduction of labor } \\
\text { input }\end{array}$ & 4 & 8,0 & 0,3 & 32 & 1,2 \\
\hline $\begin{array}{l}\text { Report on photography } \\
\text { of a working day }\end{array}$ & 4 & 2,5 & 0,15 & 10 & 0,6 \\
\hline $\begin{array}{l}\text { Logging(filing) of } \\
\text { standards and rates }\end{array}$ & 5530 & 0,14 & 0,01 & 774 & 55 \\
\hline Total & & & 2187 & 199 \\
\hline
\end{tabular}

Table 3. Calculation of Labor Input of Performed Work on Labor Standardization in a Shop of one of the Samara Industrial Enterprises

Source: It is drawn by the Authors according to the Research Results

The results of the conducted analysis of the quality of differences in individual labor productivity are mutually standards, functioning at industrial enterprises of the repaid. Calculations of deviation of percent of Samara region, have shown that the bigger amount of performance of standards on a group of shops from an workers in the analyzed group, the more precisely the average percent over one of the Samara enterprises are coefficient of performance of standards characterizes the given as an example in the table 4 (Semenova \& average intensity of standards in this group since Schekoldin, 2016) [30].

\begin{tabular}{|c|c|c|c|c|c|c|c|c|}
\hline $\begin{array}{l}\text { Groups of } \\
\text { shops }\end{array}$ & $\begin{array}{l}\text { Amount } \\
\text { of } \\
\text { employees } \\
\text { (ni) }\end{array}$ & $\begin{array}{l}\text { Percent of } \\
\text { performance } \\
\text { of standards } \\
\text { (Cpsi) }\end{array}$ & $\sqrt{n_{i}}$ & $\mathrm{M}, \%$ & $\begin{array}{l}Q_{i} \\
\%\end{array}$ & 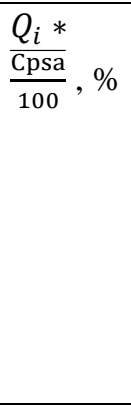 & $\begin{array}{l}\text { Absolute } \\
\text { deviation of } \\
\text { the level of } \\
\text { performance } \\
\text { of standards } \\
\text { from the } \\
\text { average over } \\
\text { an enterprise }\end{array}$ & $\begin{array}{l}\text { Deviation of } \\
\text { the level of } \\
\text { performance of } \\
\text { standards from } \\
\text { the average } \\
\text { over an } \\
\text { enterprise by } \\
\text { means of } \\
\text { intensity of } \\
\text { standards (Di) }\end{array}$ \\
\hline Blanking & 107 & 119,39 & 10,34 & 33,0 & 3,19 & 5,22 & $-44,11$ & - \\
\hline Machine & 240 & 168,80 & 15,49 & 33,0 & 2,13 & 3,48 & 5,30 & 1,82 \\
\hline $\begin{array}{l}\text { Blanking- } \\
\text { stamping }\end{array}$ & 158 & 145,69 & 12,57 & 33,0 & 2,63 & 4,29 & $-17,81$ & - \\
\hline Assembly & 212 & 233,63 & 14,56 & 33,0 & 2,27 & 3,71 & 70,13 & 66,42 \\
\hline
\end{tabular}


Helix Vol. 8(5): 3615- 3628

\begin{tabular}{|l|l|l|l|l|l|l|l|l|}
\hline $\begin{array}{l}\text { Machine- } \\
\text { assembling }\end{array}$ & 487 & 153,00 & 22,07 & 33,0 & 1,50 & 2,44 & $-10,50$ & - \\
\hline Power cable & 207 & 166,70 & 14,39 & 33, & 2,29 & 3,75 & 3,20 & 0,55 \\
\hline $\begin{array}{l}\text { Total over an } \\
\text { enterprise }\end{array}$ & 1411 & 163,50 & & & & & & \\
\hline
\end{tabular}

Table 4. Calculations of Deviation of Percent of Performance of Standards on Groups of Shops from an Average over an Enterprise

The functioning standards at the investigated industrial standards. It is implemented according to such indicators enterprises of the Samara region are studied and analyzed as a set of variate values, an average squared deviation of with account of quantitative assessment of distribution of the level of performance of standards and a variation workers according to the level of performance of coefficient (Table 6)

\begin{tabular}{|l|l|l|l|l|l|l|l|l|l|l|}
\hline Amount of employees, having \% of performance of standards & $\begin{array}{l}\text { Average } \\
\text { performance } \\
\text { of } \begin{array}{l}\text { output } \\
\text { standards, } \%\end{array}\end{array}$ & $\begin{array}{l}\sigma, \\
\begin{array}{l}\text { Groups of } \\
\text { shops }\end{array}\end{array}$ & $\begin{array}{l}\text { Under } \\
100 \%\end{array}$ & $\begin{array}{l}110 \% \\
110-\end{array}$ & $\begin{array}{l}130- \\
150 \%\end{array}$ & $\begin{array}{l}150- \\
250 \%\end{array}$ & $\begin{array}{l}\text { Over } \\
250 \%\end{array}$ & Total & \\
\hline Blanking & 21 & 27 & 36 & 19 & 3 & 1 & 107 & 119,39 & 22,9 & 19,2 \\
\hline Machine & 17 & 22 & 24 & 42 & 118 & 17 & 240 & 168,8 & 48,0 & 28,4 \\
\hline $\begin{array}{l}\text { Blanking- } \\
\text { stamping }\end{array}$ & 34 & 21 & 25 & 24 & 46 & 8 & 158 & 145,69 & 43,1 & 29,6 \\
\hline Assembly & 0 & 1 & 1 & 2 & 67 & 141 & 212 & 233,63 & 38,2 & 16,4 \\
\hline $\begin{array}{l}\text { Machine- } \\
\text { assembling }\end{array}$ & 56 & 64 & 57 & 101 & 206 & 3 & 487 & 153,0 & 44,0 & 28,8 \\
\hline Power cable & 22 & 7 & 17 & 38 & 118 & 5 & 207 & 166,7 & 44,2 & 26,5 \\
\hline
\end{tabular}

Table 5. Distribution of Workers according to the Level of Performance of Standards on Groups of Shops. Source: It is drawn by the Authors according to the Research Results.

The analysis has shown significant differences in standards, which has been calculated by us - the degree intensity of standards between groups of shops. The of progressiveness of standards. Calculations of the biggest dispersion of the level of performance of specific weight of technically based standards on a group standards is observed in machine shops, the smallest - in of subdivisions of one of the Samara industrial enterprises blanking shops. The final indicator of quality of are presented in the Table 7.

\begin{tabular}{|l|l|l|}
\hline A group of enterprise shops & $\begin{array}{l}\text { Coefficient of performance of } \\
\text { standards, \% }\end{array}$ & $\begin{array}{l}\text { Specific weight of technically based } \\
\text { standards, \% }\end{array}$ \\
\hline Blanking & 119,39 & 54,4 \\
\hline Machine & 168,8 & 30,6 \\
\hline Blanking-stamping & 145,69 & 72,3 \\
\hline Assembly & 233,63 & 51,7 \\
\hline Machine-assembling & 153 & 62,6 \\
\hline Power cable & 166,7 & 16,5 \\
\hline
\end{tabular}

Table 6. The Degree of Reasonability of Standards according to a Group of Subdivisions of the Samara Industrial Enterprise

Source: It is drawn by the Authors according to the Research Results. 
According to the table 7 it is visible that the largest specific weight of technically based standards $(72,3 \%)$ is in blanking-stamping shops, the smallest $(16,5 \%)-$ in power cable shops. At the same time, the accurate interrelation between the level of performance of standards and the specific weight of technically based standards is not observed. Therefore, the results of the conducted research show that considerable excess of percent of performance of standards by employees of some Russian industrial enterprises over its optimum value $(100 \%-105 \%)$ is mainly reached due to use of nontensional work standards.

\section{Discussion}

Issues of labor standardization in Russia are being discussed more often in economic and administrative literature, periodicals. In conditions of sanctions from the USA and the European Union, Russian enterprises have some difficulties: increase in production costs because of rise in value of production resources, and as a result, decrease in production output. Reduction of wage rates at the increasing amount of work leads to the growth of social strain. Domestic practice demonstrates that time and output standards are adjusted to the developed wage rates. The standards are usually of payment character and are obviously underestimated. The situation of fifties of the 20th century, when many employees fulfilled standards by 150 - 200 percent, corresponds to the modern situation with employee compensation at some enterprises of the country and, in particular, the Samara region. A number of the Samara industrial enterprises are characterized by rather high level of performance of standards (up to 150 - 180\%) by piece-workers at quite low specific weight of a tariff part in the salary (40$55 \%$ ) The conducted studies show that owing to objective and subjective reasons the majority of heads of various management levels are not ready to work in conditions of high-quality labor standardization. As for hired workers, in present realities, some have become disaccustomed to work in intense standards, and others do not want or can not work on qualitatively calculated standards.

\section{Conclusion}

Work on improvement of labor standardization at Russian enterprises should be carried out in the following main directions:

1. The biggest possible expansion of the sphere of labor standardization (coverage of all employees and activities on labor standardization), which would provide measurement and assessment of labor of any category of workers.

2. Improvement of the quality of existing standards, their maximum approach to the level of necessary labor input due to a wider use of the centrally developed standards and increase in reasonability of norms (standards) with account all of the factors influencing the value of labor input.

3. Improvement of regulatory and methodological base of labor standardization, i.e. expansion of development of the interindustrial and industrial standards as recommended ones; it allows not only providing substantial support of enterprises, especially to small ones, but also excluding duplication of development of similar standards, focusing an enterprise on the progressive level of labor organization.

4. Human resourcing: Realization of the specified tendencies in many respects depends on vocational training of the experts, who are engaged in organization and standardization of labor. For this purpose, it is necessary to provide training of specialists in higher education institutions according to applications of enterprises and professional development of enterprise employees.

5. Development of international cooperation: It is expedient to develop business connections with international and national organizations, advanced enterprises, which are engaged in scientific and practical activities in the field of organization of labor standardization.

Now, when scientific and technological progress flourishes, to be effective and competitive in the market can be only enterprises, which are regularly updating the technological, information base and applying the latest computer technologies.

Studying of various references and experience of a number of enterprises has shown that this problem in Russia is insufficiently worked. Thus, development of the integrated system of work automation in the field of labor standardization is necessary. In modern conditions, it is an important tendency of improvement of labor standardization at enterprises.

\section{References}

1. Simonova, M.V., Ilyukhina, L.A., Bogatyreva, I.V., Vagin, S.G., Nikolaeva, K.S. (2016).Conceptual approaches to forecast recruitment needs at the regional level. International Review of Management and Marketing, Vol. 6(S5), pp. 265-273. 2. Sukhanova, A.V. \& Pikalin, Yu.A. (2009). Microelement work standardization. Science and business: development ways, Vol. 12 (78), pp. 50-52.

3. Shchekoldin, V.A. (2013). Automation of work on labor standardization with the use of information technologies at industrial enterprises: monograph. Electronic publication. Publishing house of Samara State University of Economics, Samara.

4. Miuskova, R.P., \& Kireeva, L.E. (2013). Development and Renewal of Time Standards By 
Means of The Method of Index Numbers. Standardization and Remuneration of Labor in Manufacturing Industry, Vol. 4, pp. 59-65.

5. Zainullina, M.R. (2012). Modern approaches to the problem of labor standardization. Russian entrepreneurship, Vol. 13(23), pp. 52-56.

6. Maximov, D.G. (2014). Emergence and development of microelement work standardization. Vestnik of Udmurt State University. Series «Economics and Law», Vol. 1, pp. 68-71.

7. Malinin, S.V., Bakhtizina, A.R. \& Startsev, G.N. (2016). Methods of work standardization in the coordinate system of modern production. Vestnik of Ufa State Petroleum Technological University. Science, education, economics. Series Economics, Vol. 3(17), pp. 90-101.

8. Byichin, V.B. \& Novikova, E.V. (2018). Labor standardization as an element of effective incompany management in modern conditions. Labor Economics, 5(1), 110-115.

9. Miuskova, R.P. (2004). Optimization of work flows with the use of mathematical methods and microelement time standards $.2 \mathrm{~d}$ edition, revised and enlarged, Ser. 134). Moscow: RUSAKI.

10. Barnes, R.M. (1980). Motion and time study: Design and measurement of work. New York: Wiley.

Meyers, F.E. \& Stewart, J.R. (2002). Motion and Time Study for Lean Manufacturing, third ed. Prentice Hall, New Jersey, USA.

11. Khalid, S.Al-Saleh. (2011). Productivity improvement of a motor vehicle inspection station using motion and time study techniques. Journal of King Saud University - Engineering Sciences. Vol. 23, pp. 33-41.

12. Maynard, H.B., Stegemerten, G.J. \& Schwab, J.L. (1948). Methods-time measurement. New York, NY, US: McGraw-Hill, 176 p.

13. Karger, D.W. \& Bayha, F.H. (1987). Engineered work measurement: The principles, techniques, and data of methods-time measurement background and foundations of work measurement and methods-time measurement, plus other related material. New York, N.Y: Industrial Press.

14. Puvanasvaran, A.P., Mei C.Z. \& Alagendran, V.A. (2013). Overall Equipment Efficiency Improvement Using Time Study in an Aerospace Industry. Procedia Engineering, Vol. 68, pp. 271 277.

15. Loktev, V.G. (2006). Labor standardization: Textbook. Minsk: BSEU, 433 p.

16. Shchekoldin, V.A., Bogatyreva, I.V. \& Ilyukhina, L.A. (2018). Use of Information Technologies in labor standardization. Labor Economics, Vol. 5(1), pp. 34-39.
17. Shutina, O.V. (2009). Labor standardization as a business-process. Vestnik of Omsk University. Series Economics, Vol. 2, pp.19-25.

18. Shchekoldin, V.A. (2011). Labor standardization at an enterprise: state and ways of improvement. Problems of improvement of production organization and management of industrial enterprises: interuniversity collection of scientific papers, Issue 1, SSEU publishing house, Samara.

19. Bogatyreva, I.V. (2016). Issues of labor standardization in Russia. Science of the XXI century: relevant development tendencies: collection of scientific articles of the IV International virtual scientific and practical conference, dedicated to the 85th anniversary of Samara State University of Economics. Issue 2: in 2 parts. Publishing house of Samara State University of Economics: Samara, pp. 159-162.

20. Shchekoldin, V.A., Bogatyreva, I.V. \& Ilyukhina, L.A. (2017). Quality of standards at Russian enterprises: problems and ways of their solution. Economic Sciences, Vol. 9(154), pp. 21-28. 21. Collewet, M. \& Sauermann, J. (2017). Working hours and productivity. Labour Economics, 47, pp. 96-106.

22. Durana, C., Cetindereb, A. \& Emre Aksuc, Y. (2015). Productivity improvement by work and time study technique for earth energy-glass manufacturing company. Procedia Economics and Finance, Vol. 26, pp. $109-113$.

23. Espinosa-Garza, G., Loera-Hernández,I., \& Antonyan, N. (2017). Increase of productivity through the study of work activities in the construction sector. Procedia Manufacturing, Vol. 13, pp. 1003-1010.

24. Vaisburd, V.A., Simonova, M.V., Bogatyreva, I.V., Vanina, E.G., Zheleznikova, E.P. (2016). Productivity of labour and salaries in Russia: Problems and solutions. International Journal of Economics and Financial Issues, Vol. 6(S5), pp. 157165.

25. Riley, R. \& Rosazza Bondibene, C. (2017). Raising the standard: Minimum wages and firm productivity. Labour Economics, Vol. 44, pp. 27-50.

26. Kichigin, A.V. (2014). Issues of labor standardization at enterprises. Modern issues of science and education, Vol. 5, pp. 56-59.

27. Lanza, G., Stoll, J., Stricker, N., Peters, S., Lorenz, C. (2013). Measuring Global Production Effectiveness. Procedia CIRP, Vol. 7, pp. 31-36. doi:10.1016/j.procir.2013.05.006.

28. Shchekoldin, V.A. (2015). Main tendencies of automation of work on labor standardization at an enterprise. Problems of enterprise development: theory and practice: materials of 14th International scientific-practical conference. Publishing house of 
Helix Vol. 8(5): 3615- 3628

Samara State University of Economics, Samara, pp. 118-121.

29. Semenova, E.G., \& Shchekoldin,V.A. (2016). Mathematical and statistical analysis of the condition of labor standardization at an enterprise. Issues of improvement of production organization and management of industrial enterprises: interuniversity , Issue 1. SSEU publishing house, Samara, pp. 119124 